\title{
Anterior tarsal tunnel syndrome について
}

\author{
福岡大学整形外科 \\ 松 崎 昭 夫・木 梨 博 史 \\ 香椎外科
}

清 成 正 智

\section{Anterior Tarsal Tunnel Syndrome}

by

\section{Akio Matsuzaki}

Department of Orthopedic Surgery, Chikushi Hospital, Fukuoka University, Fukuoka, Japan

Masatomo Kiyonari

Kashii Geka Clinic, Fukuoka, Japan

\begin{abstract}
The anterior tarsal tunnel syndrome, described by Marinacci in 1968, is an entrapment neuropathy of the deep branch of the peroneal nerve beneath the inferior extensor retinaculum. Five cases of this syndrome are presented. The patients have complained pain or paresthesia in front of the ankle or dorsum of the foot. Hypaesthesia and hypoalgesia were found in sensory area of the deep peroneal nerve which was distinctly sensitive to pressure under the inferior extensor retinaculum. It is necessary to take care in making examinations on a patient who shows symptoms on the same place so as to avoid misdiagnosis and useless diagnostic procedures and treatment.
\end{abstract}

\section{は じめに}

1968 年 $\left.M a r i n a c c i{ }^{5}\right)$ は足関節前面で前脛骨筋腱，長 母趾伸筋腱, 足背動脈及び伴行静脈, 深腓骨神経など が通る下伸筋支帯下を anterior tarsal tunnel とよび, そこで起る圧迫性神経障害を anterior tarsal tunnel syndrome の名で記載した。この絞扼性神経炎は多いも のではないが, 足関節前面より足背にかけて痛みや知 賞障害を訴える患者の診察に際して鑑別にあげるべき 疾患の一つであると考える。一般に馴染のない病名で あるので注意を喚起するために自験例を報告すると共 に本疾患について述べる。

\section{症例}

1984 年 1 年間に著者が経験した本症は 5 例である (表 1 ). 年齢は $34 \sim 67$ 才, 男 $2:$ 女 3 , 病気の期間 は 2 日より約 1 カ月にわたっていた。症状：患者が訴 えた症状及び所見は表 Iにまとめて示す。いずれも足
関節前面付近の疼痛又は知覚異常を訴えている. 他の 絞扼性神経炎同様この場合も詳しい痛みの場所はわか つて扔らず, 足関節前面より足背あたりと訴えている. 時には母趾までと訴える例もある，感覚異常は針で刺 すようなチクチクした感じや灼けるような感じの他ジ ンジンする感じなどである. その他安静時の痛みや夜 間に痛みが増強するなどの訴えもみられている．他覚 的所見：下伸筋支帯下で長母趾伸筋腱下ょり神経が外 側に出る部分に圧痛を認め, 第 I, II 指間背側の触覚, 痛覚鈍麻を認めている。圧痛は全例上記部位で認めら れ, 足の他動的底屈で増強し, 背屈で軽減した例や母 趾に痛みが放散する例もみられた。この他遠位の足背 筋膜浅層より皮下に出る部分にも圧痛を認めた例が 2 例みられた。運動枝の麻㿁に起因する短趾伸筋の萎縮 や指の伸展力減弱などの所見はみなかった。全例近位 には異常所見を認めなかった。臨床的に診断がついた ため電気生理学的検查は行っていない.

病因：捻挫後に起ったと思われる 1 例以外は不明で 
表1〈自験 5 症例の病像〉

\begin{tabular}{|c|c|c|c|c|c|c|}
\hline 症例 & 年令 & 性 & 患 者 の 訴 え & 所 & 治 & 備 \\
\hline 1 & 29 & 우 & $\begin{array}{l}2 \text { ～} 3 \text { 日来右足関節前面辺り } \\
\text { と母指背側に痛みを感じる。 } \\
\text { 足関節部の痛みは夜間に強く, } \\
\text { ズキズキした痛みである。 }\end{array}$ & $\begin{array}{l}\text { 深腓骨神経支配域の知覚鈍麻 } \\
\text { と下伸筋支帯部及び末梢の浅 } \\
\text { 足背筋膜出口に圧痛を認める。 } \\
\text { 圧痛は近位が強い。更に近位 } \\
\text { には病的所見を認めない。 }\end{array}$ & $\begin{array}{l}\text { ステロイド剤＋局麻 } \\
\text { 剤浸潤 } 1 \text { 回 }\end{array}$ & $\begin{array}{l}\text { 半年前から総腓骨神 } \\
\text { 経, 中間足背皮神経, } \\
\text { 足根管症候群などで } \\
\text { 治療を受け治った後 } \\
\text { でおこった。 }\end{array}$ \\
\hline 2 & 34 & $\hat{\delta}$ & $\begin{array}{l}\text { 1ヶ月来右足関節辺りより母趾 } \\
\text { 趾背にかけ夜間・安静時に針 } \\
\text { を刺す様なチクチクした痛い } \\
\text { 感じがある。 }\end{array}$ & $\begin{array}{l}\text { 深腓骨神経支配域の知覚鈍麻 } \\
\text { と下神経笳支帯部の圧痛を認 } \\
\text { める。 }\end{array}$ & 同上処理 1 回 & \\
\hline 3 & 41 & 우 & $\begin{array}{l}1 \text { 週来足関節前面辺りの痛み } \\
\text { を感じる。 }\end{array}$ & $\begin{array}{l}\text { 深腓骨神経支配域の知覚鈍麻 } \\
\text { と下伸筋支帯部の圧痛 (母趾 } \\
\text { に放散) を認める。足関節の } \\
\text { 他動的伸展で圧痛は増強し, } \\
\text { 屈曲でま弱まる。 } \\
\text { 近位に病的所見を認めない。 }\end{array}$ & $\begin{array}{l}\text { 1週放置すると増悪。 } \\
\text { 同上処置 } 1 \text { 回 }\end{array}$ & 急性腰痛症で入院中 \\
\hline 4 & 50 & 우 & $\begin{array}{l}\text { 1ヶ月前足関節捻挫, 治療を続 } \\
\text { けているが, まだ正座すると } \\
\text { 痛い。 }\end{array}$ & $\begin{array}{l}\text { 捻挫に起因すると思われる所 } \\
\text { 見なし。腓骨神経支配域に軽 } \\
\text { 度の知覚鈍麻と下伸筇支帯部 } \\
\text { の圧痛を認めない。 }\end{array}$ & 塗布剤にて治療 & \\
\hline 5 & 67 & 우 & $\begin{array}{l}3 \text { 週来右足趾全体が灼ける様 } \\
\text { に感じる。痛いというより湯 } \\
\text { につけてあい感じ。 } \\
\text { この1週来痛みが足関節前面 } \\
\text { にくると訴える。 }\end{array}$ & $\begin{array}{l}\text { 足底の知覚鈍麻と足底神経の } \\
\text { 母趾外転筋下の入口の痛 } \\
\text { を認める。同時に深腓骨神経 } \\
\text { 支配域の知覚鈍麻と浅足背筋 } \\
\text { 膜出口の圧痛を認める。1 週 } \\
\text { 後は下伸筋支配下の圧痛を認 } \\
\text { める。近位には病的所見を認 } \\
\text { めない。 }\end{array}$ & $\begin{array}{l}\text { ステロイド剤＋局麻 } \\
\text { 剤浸潤 } 1 \text { 回 }\end{array}$ & $\begin{array}{l}\text { 初診時には足底神経 } \\
\text { 絞扼点と浅足背筋膜 } \\
\text { 出口に浸浸。1 週後 } \\
\text { は下伸筋支帯下に浸 } \\
\text { 潤。 }\end{array}$ \\
\hline
\end{tabular}

あった，履物にも特に問題は認めなかった。

治療：4 例はステロイド剤と局麻剤の絞扼点への浸 潤を行い, いずれも 1 回の浸潤で治癒している. 残り 1 例は消炎鎮痛剂の塗布のみで治癒した。

\section{考察}

自験例と共に文献例 10 例につき検討してみた ${ }^{12) 4) 5)}$. 症状としては足関節前面, 足背又は母趾にかけての疼 痛又は感覚異常を訴えている。その他しめつけられた 感じやシビレ感もみられている。痛みは安静で強く, 足を動かすと軽くなる，又夜間痛がひどく，眠りを妨 げられるものが文献例に 4 例みられており, 我々の症 例でも同じ割合の 2 例でみられている.之等の症状は 手根管症候群によく似た症状である，必熱感を訴える ものは文献例 2 例, 自験例 1 例であった. 自験例の患 者は“痛いというよりあつい湯につけたような感じ” と述べている，他に履物が悪いこと，足の肢位で症状 が変化することに気付いている患者もみられている. 観察される所見としては第一趾間背側に種々の程度の
知覚障害がみられている. 更に下伸筋支帯下, 長母趾 伸筋腱下より神経が出るあたりに圧痛を認めた。文献 例では記載のない 4 例を除くと同部に圧痛を認めた記 載のあるもの 3 例, Tinel 徵候が記載されているもの 3 例がある，圧痛が記載されたもののうち 2 例は圧迫時 末梢の異常感覚を訴えている．文献例では筋萎縮のみ られた例が 4 例があり，内 2 例は筋枝単独例である。 全例筋電図, 神経伝導速度, 遠位潜時などが測定され, 陽性所見がみられている。著者等は筋萎縮を伴った症 例を経験していない. 又電気生理学的検査も下記の理 由で行わなかった。筋枝のみの障害を除けば一般には 臨床的に診断可能と考えること，3例は開業医の外来 で診察した症例で，わざわざ検査のため病院に送るほ どのことがなかったこと，残り 2 例も改めて検査を受 けさせねばならない程の症状がなかったこと及び初期 又は軽症例では筋電図所見は大して診断の助けになら ず臨床所見を詳しくみれば診断出来るからである，文 献例は症状発現より検査までの期間がかなり長いこと はも考慮しなければならない，我々の症例はせいぜい 
1 力月未満の軽症例であり，筋電図検査を行っても多 分陽性所見は得られなかったと思われている。神経伝 導速度は他覚的検查所見の記録として欲しいとは思っ たが上記理由で行わなかった。腓骨頭と足関節部間の 運動神経伝導速度が正常で足関節を越える部分が遅れ を示せば診断根拠として申し分ない記録が得られるこ とになる，検査可能な施設では診断のためだけではな く，治療効果判定の資料としても検查を行うことは結 構なことと考える．勿論筋に所見が見られる場合や手 術を考える場合は経過観察の他覚的手段として利用す べきである，原因として種々の外傷，靴特にハイヒ一 ル，ぴったりしまったブーツなどがあげられているが 不明のものもある ${ }^{1224)}$. 我々の例では 4 例が不明であっ た。診断は前に述べた病歴, 知覚障害範囲及び絞扼点 の圧痛で可能で，鑑別にあげさえすれば容易である。 筋萎縮があ机ば更に容易である。電気生理学的検査は 設備があれば行って参考にする。筋枝のみの場合は判 り難いことも考えられるがこの場合は電気生理学的検 查が助けになる，本症は一般に馴染がない疾患である が，足関節前面より足背母趾にかけての痛みや知覚障 害を訴える患者を診察する場合には鑑別にあげる必要 がある，同様な部位に症状を訴える疾患としては椎間 板へルニヤによる第 5 腰神経根の症状, 総腓骨神経, 腓骨神経浅枝及び深枝が筋膜を貫通する部での絞扼性 神経炎, 足部の外傷, 足関節炎などがあげられる113). いずれも詳しく所見をみればそれぞれ固有の症状を示 しいるはずである．末梢の足背筋膜浅層出口の障害は 訴えや症状が似ることがあるが, 圧痛の場所が違って いる．ただし，症例 $1 ， 5$ のように両方で症状を起こ したり，経過中に場所が変わることがあるので神経の 近位から遠位までの絞扼の可能性がある場所は調べて おく，当然上にあげた疾患と合併してみられることも あるので，一つの病気がみつかったからと他疾患の鑑 別を省くことは許されない。一般に足の絞扼性神経炎 では筋の所見を調べることがむつかしい.しかし本症 では短趾伸筋が大変見易く，触れ易い場所にあるため 筋所見の観察も比較的容易である。筋収縮を触れなが らその機能を調べたり ${ }^{2)}$,筋電図を利用して筋の活動性 を調べてもよい.治療はまず保存的に行うべきである. 原因として靴が疑われたら靴を変えさせて様子をみる。 足の変形が関与している場合は装具使用も考慮する. 軽症では自然治瘾も期待出来るので症例 4 のような簡 単な処置で様子をみるのも一法である。しかし日常生
活を妨げる程度の痛みがある患者に対してはステロイ ド剤と局麻剤を絞扼点に浸潤することを考える，之て 診断確認と同時に痛みせとれるので患者も安心する。 効果があれば週 1 回の間隔で浸潤を行う．浸潤で症状 がとれても麻酔がきれると再び症状が出るものや $1 \sim 2$ 日しか効果のないものは再度浸潤を行ってみる。皇れ で同じ結果なら観血的治療を考えるべきであるが, 我々 は手術例の経験をもたない. 文献例では Borges 等の 1 例で手術が行われている. 彼等の例では長母趾伸筋と 神経上膜間に $2 \mathrm{~mm}$ のバンドによる連結がみられたと 述べている．絞扼性神経炎の手術では一般的に云える ことであるが，本症でも下伸筋支帯を切離し，長母趾 伸筋下を調べるだけでなく術前の所見も参考にして上 下も調べ，障害となる可能性のあるものを除いておく ことが必要であろう．文献例に比べると我々の症例は 軽いと考えるが，このような症例は注意してみれば日 常の外来でそんなに稀なものではないように思われる。

結

\section{び}

anterior tarsal tunnel syndrome に対する注意を喚 起するため本症につき報告した。自験例 5 症例に文献 例 10 例を加えて検討した。 それに基づき本症の症状, 臨床所見，診断，治療などにつき述べた．更に足関節 前面より足背，母趾にかけての疼痛又は感覚異常を訴 える患者の診察時には本症を鑑別にあげるべきことを 述べた。

\section{参 考 文 献}

1) Borges, L. F. et al.: The anterior tarsal tunnel syndrome. J. Neurosurg. $54:$ 89-92, 1981.

2) Gessini, L. et al. : The anterior tarsal syndrome. J. Bone Joint Surg. 66-A : 786-787, 1984.

3) Kopell, H. P. \& Thompson, W. A. L.: Peripheral Entrapment Neuropathies. 2nd ed. Robert E. Krieger Huntington, New York 1976.

4) Krause, K. H. et al. : The anterior tarsal tunnel syndrome. J. Neurol. $217: 67-74,1977$.

5) Marinacci, A. A. : Neurological syndrome of the tarsal tunnels Bull. Los Angels Neurol. Soc. 33 : 90 $-100,1968$.

質 問

産業医科大学 伊地知正光

(1) Anterior Tarsal Tunnel の部分の解剖学的な varation は少ないものでしょうか.

(2) 同部での神経の圧迫は肢位によってどのように 
なりますか.はきもので悪いのは何でしょうか. 福岡大学 松崎 昭夫

\section{解 答}

(1) 神経走行が一定か？について.

ほぼ一致した走り方をしていると考えます。

(2) 肢位による変化について.

引用文献に調べたものがありますが, 足の底屈, 趾 背屈が神経を緊張させる様です。之はハイヒールはい
た肢位で, 原因としてハイヒールやカカトの高いぴっ

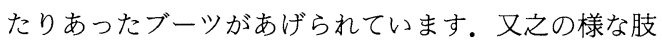
位での圧痛増強もみられます。

実際解剖してみるとすぐ distal に距骨頭があり, 底 屈で緊張が増すのがみられます。

(3) anterior tiblal syndrome について

之は全く違う機転のマヒで compartment 中の症状で す. 当然深枝のマヒも出るわけです. 